\title{
TEACHING COUNTRY STUDIES OF ENGLISH-SPEAKING COUNTRIES IN DISTANCE EDUCATION
}

\author{
Vdovenko T.O., Ph.D. in Philology (Izmail)
}

The article deals with the peculiarities of teaching English in the framework of the subject "Country studies" in higher educational institutions during the Pandemic 2020. High-quality foreign language proficiency contributes to the spread of cross-cultural ties and contacts, provides an opportunity to study and effectively use the foreign experience of cross-cultural communication, use modem information technologies, participate in international congresses and seminars, and take internships in foreign countries to improve professional training.

In the modern world, international relations are an important way of a nation's survival in the economic crises following the pandemic COVID 19. The progressive development of international relations determines the orientation of modern methods of teaching foreign languages to the real-life conditions of communication. The final result of training is aimed not only at language competence, but also the assimilation of a huge amount of extra-linguistic information necessary for adequate communication and mutual understanding.

The aim of the article is to reveal the existing problems of the modem education system and English teaching in a new reality. This article suggests the way of learning English Country studies in the conditions of distance education.

To simplify the mutual understanding between countries on different issues, it is necessary to learn the main peculiarities of a culture of other people, their historical and ethnocultural background.

Distance learning has been widely developed in 2020-2021 in many universities (institutions of higher education) in Ukraine. The article deals with the problem of introducing a new system of training, implementing the state education program in the framework of distance leaming, and the possibility of solving it through modern technologies, the use of which allows combining the advantages of fulltime education, while offering the convenience and flexibility of remote work, namely: communication in a team, a sense of belonging, access to individually created materials and classes in comfortable conditions for students.

The hybrid (blended) form of education (both online and offline) allows for a short time to cover a wider range of information about English-speaking countries in the country studies classes, to present species with their flora and fauna, local populations, and customs colorfully.

The study of cultural aspects of teaching country studies of English-speaking countries is a promising area.

Key words: communication, Country Studies, English-speaking countries, foreign languages, teaching.

(C) Vdovenko T., 2021 
Вдовенко Т.О. Викладання країнознавства англомовних країн в умовах дистанційної освіти. Стаття розглядає особливості викладання 3 предмету «Країнознавство англомовних країн» у закладах вищої освіти в період пандемії 2020 року. Якісне володіння іноземною мовою сприяє поширенню міжкультурних зв'язків та контактів, надає можливість вивчати та ефективно використовувати іноземний досвід міжкультурного спілкування, користуватися сучасними інформаційними технологіями, брати участь у міжнародних конгресах та семінарах, проходити стажування в іноземнихдержавах з метою вдосконалення фаховоїпідготовки.

Міжнародне співробітництво $€$ важливим способом виживання нації в сучасному світі у зв'язку з економічними кризами під час пандемії COVID 19. Розвиток міжнародних відносин визначас орієнтацію сучасних методів навчання іноземних мов на реальні умови спілкування.

Кінцевий результат навчання спрямований не тільки на мовну компетенцію, а й на засвоєння величезної кількості екстралінгвістичної інформації, необхідноїдля адекватного спілкування і взаєморозуміння.

Мета статті - розкрити існуючі проблеми сучасної системи освіти та викладання англійської мови в нових реаліях. Стаття пропонує спосіб вивчення англійської мови в умовах дистанційного навчання. Щоб оптимізувати взаєморозуміння між країнами 3 різних питань, необхідно вивчити основні особливості культури інших народів, історію та культуру.

Дистанційне навчання отримало широкий розвиток у 2020-2021 роках у багатьох університетах України. У статті розглядається проблема впровадження нової системи навчання, яка реалізує державну освітню програму в рамках дистанційного навчання, і можливість їі вирішення за допомогою сучасних технологій, використання яких дозволяє поєднувати переваги очного навчання, забезпечуючи при цьому зручність і гнучкість дистанційної роботи, а саме: спілкування в колективі, почуття причетності, доступ індивідуально створених матеріалів і занять в комфортних для студентів умовах.

Гібридна (змішана) форма навчання (як онлайн, так і офлайн) дозволяє за короткий час охопити на заняттях 3 країнознавства більш широке коло інформації про англомовні країни, їх флору і фауну, місцеве населення та звичаї. Використання різних ІКТ технологій, у тому числі мобільних додатків, сприяє вдосконаленню проведення лекцій і семінарських занять із предмету «Країнознавство англомовних країн».

Перспективним $\epsilon$ вивчення культурологічних аспектів викладання країнознавства англомовних країн.

Ключові слова: англомовні країни, викладання, іноземні мови, комунікація, країнознавство.

Вдовенко Т.А. Обучение страноведению англоязычных стран в условиях дистанционного образования. В статье рассматриваются особенности преподавания предмета «Страноведение англоязычных стран» в учреждениях высшего образования в периодпандемии 2020 года. 
Качественное владение иностранным языком способствует укреплению межкультурных связей и контактов, дает возможность изучать и эффективно использовать зарубежный опыт межкультурной коммуникации, применять современные информационные технологии, участвовать в международных конгрессах и семинарах, проходить стажировки в зарубежных странах с целью повышения профессиональной подготовки.

В современном мире международные отношения являются важным способом выживания нации в связи с экономическими кризисами в период пандемии COVID 19. Развитие международных отношений определяет ориентацию современных методов обучения иностранным языкам на реальные условия общения. Конечный результат обучения направлен не только на языковую компетенцию, но и на усвоение огромного количества экстралингвистической информации, необходимой для адекватного общения и взаимопонимания.

Цель статьи - раскрыть существующие проблемы современной системы образования и преподавания английского языка в новых реалиях. В данной статье предлагается способ изучения английского языка в условиях дистанционного обучения.

Чтобы оптимизировать взаимопонимание между странами по различным вопросам, необходимо изучить основные особенности культуры других народов, их историю.

Дистанционное обучение получило широкое развитие в 2020-2021 годах во многих университетах Украины. В статье рассматривается проблема внедрения новой системы обучения, которая дает возможность с помощью современных технологий сочетать очное обучение с дистанционной работой, а именно: общение в коллективе, чувство сопричастности, доступ к индивидуально созданным материалам и занятиям в комфортных для студентов условиях.

Гибридная (смешанная) форма обучения (как онлайн, так и офлайн) позволяет за короткое время охватить на занятиях по страноведению более широкий круг информации об англоязычных странах, наглядно представить их флору и фауну, местное население и обычаи. Использование различных ИКТ технологий, в том числе мобильных приложений, способствуют совершенствованию проведения лекций и семинарских занятий по предмету «Страноведение англоязычных стран».

Перспективным является изучение культурных аспектов преподавания страноведения англоязычных стран.

Ключевые слова: англоязычные страны, иностранные языки, коммуникация, преподавание, страноведение.

Foreign language is important in studying the culture of other people from different countries as it takes the main role in forming the thoughts of the young generation. Students can get lingua-cultural knowledge through original texts that contain plenty of lingua-cultural units of modern everyday life. 
It is very important to know the historical and ethnocultural background of the country, as it gives information about the way of life, customs, traditions, holidays and peculiarities of communication with different people, which is very important for international relations between countries.

Country studies deal with the study of language in terms of its cultural function. The main task of studying the country study material is to form a positive attitude of students to the people (native speakers of the countries, whose language they study).

Statement of the problem and its connection with important scientific and practical tasks. The relevance of the problem lies in the fact that today the progressive development of international relations determines the orientation of modern methods of teaching foreign languages to the real conditions of communication. The final result of training is aimed not only at language competence, but also the assimilation of a huge amount of extra-linguistic information necessary for adequate communication and mutual understanding, obtaining basic information about the surrounding reality. Noticeable differences in the stock of this information among speakers of different languages are mainly determined by the different material and spiritual conditions of the existence of peoples and countries, the peculiarities of their history, development, culture, socio-economic system, political system, etc.

The research represents the description of modern distance education and the attempts to teach Country studies in a new reality.

The subject of the research is the description of teaching Country Studies of English-speaking countries in teaching English as a foreign language.

Analysis of recent studies and publications dealing with the problem and serving as a basis for the research. Aspects of Country Studies have become a subject of study for many modern scientists, such as A. Gaponiv, A. Gizatulina., Yu. Kohan, V. Krasnyh, V. Maslova, M. Vozna and others. Ukrainian scientist Yu. Kogan in her dissertation thesis touched on the problem of teaching Country Studies. According to Yu. Kogan, Country Studies' competence is a set of know ledge about the country whose language is being studied, and the corresponding skills to use this knowledge in practical activities. Structural indicators of country studies competence include 1) the level of assimilation of Country Studies material; 2) the focus on the use of country studies material in future professional activities; 3 ) the ability to 
perceive the diversity and cross-cultural differences of the countries whose language is being studied; 4) the ability to work in an international context, etc.

Nowadays, despite the number of works devoted to Country Studies and the problems of the relations of language and culture there is a lack of research related to the teaching of the subject "Country Studies of English-speaking countries" in conditions of distance education.

Isolation of previously unsolved parts of a general problem. Among the unsolved parts of a general problem, we can name the peculiarities of teaching the subject "Country Studies" in higher educational institutions during the lockdown and using distance education.

Problem statement. The aim of the article is to reveal the existence of problems and difficulties in teaching Country Studies of English-speaking countries in a new reality.

The achievement of the aim involves such scientific tasks:

- to study the modern problems of distance education;

- to represent the examples of tasks in teaching Country Studies of English-speaking countries;

- to describe the perspectives for further research of teaching foreign languages in the conditions of distance education.

Presentation of the main material. The course is propaedeutic in its focus and forms students' communicative, linguistic, and sociocultural competencies.

The purpose of teaching the course is to form the student's system of modern cultural knowledge and provide the non-native student with background (extralinguistic) knowledge about the country, the language of which he is mastering, which in volume and content would be close to the background knowledge of the average native speaker of this language and culture. As a cultural science, one of the most relevant and promising areas of modern linguistics, focused on the "eternal" problem of the relationship between language, culture, and man $[7 ; 8 ; 9 ; 10 ; 11]$, this course is focused on the needs of learning a foreign language.

"Country studies of the English-speaking countries" is a selective academic discipline for training specialists of the Bachelor's level of education, the branches of knowledge (training) area/specialty "014 Secondary Education (014.02 Language and Literature (English))".

One of the first textbooks on linguocultural studies of Englishspeaking countries by domestic authors is the textbook of A. Gaponiv 
and M. Vozna "Linguocultural studies. English-speaking countries" [6], approved by the Ministry of Education and Science of Ukraine as a textbook for students of higher educational institutions (№. 14/18.21949.1 of 19.08.05). The textbook consists of 14 sections, each of which is devoted to a separate country (England, Scotland, Wales, Northern Ireland, USA, Canada, Australia, New Zealand, and the Isle of Man) and such separate units as Hawaii, Alaska, and Tasmania. The textbook offers a fresh look at various aspects of the life of these countries and provides many facts on various aspects of the culture of English-speaking nations and is recommended for students of professional faculties of higher educational institutions in Ukraine [6].

The forms and methods of current control include an oral survey of students on theoretical issues, seminars, discussions, individual tasks.

The forms of current control are seminars, independent and individual tasks. The form of intermediate control is a test. The form of final control is a credit.

The tools for diagnosing learning outcomes and criteria for evaluating learning outcomes are provided in the syllabus of the academic discipline posted on the website.

Among the tasks for independent work, we suggest a chronological table, a report using additional literature, and a presentation in PowerPoint.

A chronological table may present an essay on historical events of a country, wars, a dynasty of kings, or main achievements (e.g. "Make up a chronological chart of the British Monarchs" or "Make up a chronological chart of American presidents").

The test is carried out in a written form. It can present the answers to the questions (Against what Celtic tribes did the war last for 8 years in the 1-st century A.D.? or What was one of the last countries to be conquered by Rome?) or may suggest a multiple choice from the given answers.

The use of smartphones during classes of Country studies suggests quests and allows playing with students. The most popular among students is Kahoot. Kahoot is a game-based learning platform used in educational institutions. "Kahoot" can be used to test students" knowledge or as a break in classes. This is a relatively new service for creating online quizzes, tests, and surveys. This program can be effectively used for didactic purposes. Students can answer the tests created by the teacher from tablets, laptops, smartphones (from any 
device that has access to the Internet). Using this service is a good way to get original feedback from students.

Tasks created in Kahoot allow teachers to include photos and even video clips in them. The rate of completion of quizzes and tests is regulated by introducing a time limit for each question. The teacher can enter points for answering the questions: for correct answers and speed. The scoreboard is displayed on the teacher's computer monitor. To participate in the test, students simply need to open the service and enter the PIN code that the teacher presents from their computer. It is convenient for the student to choose the correct answer on their device. The options are represented by geometric shapes.

One of the features of Kahoot is the ability to duplicate and edit tests, which allows the teacher to save a lot of time. In addition to quizzes, we can use Kahoot to start discussions by starting with a single question, or to conduct a Survey on several questions and then start a debate. "Kahoot" not only contributes to the comprehensive development of the student's personality and increases their motivation, but also significantly optimizes the work of the teacher.

In the modern world, the use of various technologies, including mobile applications, which contribute to the improvement of the educational process, is becoming increasingly popular. Today, there is a fairly large set of information technology tools available to the teacher. Various Internet resources can be used to prepare and conduct lectures and seminars. Nowadays, the use of ICT technologies in teaching English is one of the most important aspects of improving the educational process. These technologies contribute to the development of intellectual and creative students' abilities increase their motivations. The use of these technologies helps to fill the classes with new content, creates a favorable atmosphere for working in the classroom, accelerates the learning process, and increases students' interest in the subject. The appropriate use of ICT technologies makes the classes of Country studies more entertaining and effective.

The use of Wondershare Filmora (a simple video editor) gives opportunities for ordinary users (both teachers and students) for video editing.

ThingLink interactive poster, which means "dialogue images", is used to create interactive posters, infographics, itinerary sheets, time feeds and newspapers. The peculiarity of this service is that in one drawing a huge amount of text information, embed movies, drawings 
can be collected. Created posters in ThingLink can be edited by other users without registration. With the Thinglink service, various educational materials, for example, sets of electronic didactic materials for lectures and seminars; multimedia lecture notes; travel maps; interactive posters in the form of projects on a specific topic can be created.

Interactive tests (Learning Apps) are also widely used. Among the examples of interactive tasks created on the LearningApps service, there is a game for practicing Country studies knowledge https://learningapps.org/dis play?v=pejv00wrn01 [13].

Among the creative tasks, we can suggest the game "Heads and Tails", which presents virtual trips to English-speaking countries.

It is impossible to do without distance learning in the modern world. The use of modern remote technologies, such as the digital Zoom platform and the Padlet virtual whiteboard [1], makes it possible to explain the material visually: draw, take notes, correct mistakes, and demonstrate the new words and pictures.

Among the advantages of teaching country studies in distance education is the fact, that students, who missed lectures, can find the ir content on the Moodle platform. It helps students who are ill or work or live far and can't attend classes to feel participation in the process of teaching.

Another advantage is the ability to change the virtual background, which helps to create the necessary atmosphere during the classes of country studies. By changing the background on the computer during country studies classes, the teacher creates the effect of students' presence in different countries, developing cultural aspects when exploring the sights of various English-speaking countries.

Among the disadvantages of distance teaching, we can name the problems with power supply (when the weather is windy or frosty) and bad internet connection (video and audio may disappear).

The use of information and communication technologies in classes increases the technological and information literacy of students. The conference format helps to get acquainted with the peculiarities of etiquette and rules of behavior in video communication, which is becoming more common and is used not only for communicating with classmates, but also in business conversations, training and interviews. A significant advantage for the subject results is the work with sound and the possibility of multiple viewing of the material; everything that 
was not clear can always be repeated, and listening helps to develop listening skills, which is difficult to develop in a non-language environment.

Practical knowledge of foreign languages and appropriate skills during the period of expansion of political, economic, scientific, and cultural ties of Ukraine with foreign countries will help young professionals to acquire deep knowledge in their field of science, as well as allow them to use foreign sources more widely for successful research work both within our country and the framework of international cooperation, cultural and scientific exchange.

Thus, distance learning, introduced in many universities (institutions of higher education) around the world, has been widely used in Ukraine in 2020-2021. The introduction of distance education solved the problem of implementing the state education program through modern technologies, the use of which allowed combining the advantages of full - time education, while giving the convenience and flexibility of remote work, namely, communication in a team, access to individually created materials and classes in comfortable conditions for students. The hybrid (blended) form of education (both online and offline) allows covering a wider range of information about English-speaking countries in the country studies classes in a short time, to present species with their flora and fauna, local populations, and customs colorfully.

Conclusions and perspectives of further research of the issue. Mixed or blended education (both online and offline) is recognized to be the best form of education in a new reality by the whole modern world. The use of up-to-date technologies (virtual interactive whiteboard, Filmora, and the Kahoot application) in English-speaking country studies is the ideal tool for working online. It helps to strengthen the motivation and interest of students in the language being studied, significantly facilitates the teaching process for the teacher, and brings joy to the learning process for students. Using the Kahoot app in English-speaking country studies significantly encourages the development of the internal motivation of students. They like to learn new things, have an interest in learning a foreign language, and are provided with conditions for achieving certain success. Among the creative tasks, we suggest the game "Heads and Tails", which presents virtual trips to English-speaking countries.

Among the perspectives of further research is the study of cultural aspects of teaching studies of English-speaking countries. In the modern 
world, there is a great need for a linguistic and cultural approach in teaching foreign languages.

\section{LITERATURE}

1. Азанова А.Е. Виртуальная онлайн-доска как платформа создания мини-проектов в условиях дистанционного обучения. Молодой ученый. 2020. № 13 (303). С. 205-207. URL: https://moluch.ru/archive/303/68467/ (дата обращения: 04.03.2021).

2. Антонюк Н.М., Краснолуцький К.К. Англомовні країни та Україна. Книга 1. Вінниця: Нова Книга, 2004. 272 с.

3. Антонюк Н.М., Краснолуцький К.К. Англомовні країни та Україна. Книга 2. Вінниця: Нова Книга, 2004. 240 с.

4. Арделян О.B. Lingual Country Studies: навчальний посібник для студентів старших курсів, які вивчають англійську мову як спеціальність. Кіровоград: РВВ КДПУ ім. В. Винниченка, 2005. 148 с.

5. Бутковська Н.О., Маслова Н.І. Англійські та американські свята й традиції. Харків: Видавнича група «Основа», 2012. 127 с.

6. Гапонів А.Б., Возна М.О. Лінгвокраїнознавство. Англомовні країни. Вид. 2-е. Вінниця: Нова Книга, 2018. 352 с.

7. Гизатулина А.Ф. Лингвокультурологические аспекты в лингвистическом анализе. Молодой ученый. 2018. № 16 (202). С. 329 331. URL: https://moluch.ru/archive/202/49047/ (дата обращения: 04.03.2021).

8. Коган Ю.М. Країнознавство як компонент професійної підготовки вчителів іноземної мови у вищих навчальних закладах: автореф. дис. ... канд. пед. наук: 13.00 .04 / Луганський національний педагогічний університет ім. Т. Шевченка. Луганськ, 2006. 23 с. Режим доступу: URL: https://revolution.allbest.ru/pedagogics/00451842_0.html (дата звернення: 11.03.2021).

9. Красных В.В. Этнопси холингвистика и лингвокультурология. М., 2002. 284 c.

10. Лунгу Л. Culturo logical approach to the formation of the worldview of future specialists in philological specialities in the process of professional training. Науковий вісник Ізмаїльського державного гуманітарного університету. Серія: Педагогічні науки. 2020. Вип. 49. С. 72-75. DOI: 10.31909/26168812.2020-(49)-9.

11. Маслова В.А. Лингво культурология: учебное пособие для студ. высш. учеб. заведений. М.: Академия, 2001. 208 с.

12. Таксикова Л., Бондарева С. Институт математики и информатики МПГУ. Бесплатная платформа для создания онлайн-досок Padlet. Режим доступа: URL: http://internet-for-teacher.blogspot.com/2017/ 12/padlet.html/ (дата обращения: 07.03.2021). 
13. Learning Apps. URL: https://learningapps.org/ display?v=pejv00wrn 01 . Козлова B.A. URL: https://vseuroki.pro/ doc/interaktivnye-zadaniyasozdannye-na-servise-learni-5807.html (accessed:27.03.2021).

\section{REFERENCES}

1. Azanova, A.E. (2020). Virtualnaja onlajn-doska kak platforma sozdanija mini-proektov $\mathrm{v}$ uslovijah distancionnogo obuchenija [Virtual online whiteboard as a platform for creating mini-projects in the context of distance learning]. Molodoj uchenyj [Young scientist]. 13 (303), pp. 205207. Available at: https://moluch.ru/archive/303/68467/ [Accessed 4 March 2021] [in Russian].

2. Antonjuk, N.M. and Krasnoluckij, K.K. (2004). Anglomovni krayiny ta Ukrayina [English-speaking countries and Ukraine]. Book 1. Vinnytsia: Nova Knyga [in Ukrainian].

3. Antonjuk, N.M. and Krasnoluckij, K.K. (2004). Anglomovni krayiny ta Ukrayina [English-speaking countries and Ukraine]. Book 2. Vinnytsia [in Ukrainian].

4. Ardeljan, O.V. (2005). Lingual Country Studies: navchalnyj posibnyk dlya studentiv starshyh kursiv yaki vyvchayut anglijsku movu yak specialnist. [Lingual Country Studies: a textbook for senior students studying English as a specialty]. Kirovograd: RVV KDPU im. V. Vinnichenka [in Ukrainian].

5. Butkovska, N.O. (2012). Anglijski ta amerikanski svjata j tradicï [English and American holidays and traditions]. Kharkiv: Vidavnicha grupa "Osnova" [in Ukrainian].

6. Gaponiv, A.B. and Vozna, M.O. (2018). Lingvokrayinoznavstvo. Anglomovni krayiny [Linguocultural studies. English-speaking countries]. Vinnytsia: Nova Knyga [in Ukrainian].

7. Gizatulina, A.F. (2018). Lingvokulturologicheskie aspekty v lingvisticheskom analize Linguoculturological aspects in linguistic analysis]. Molodoj uchenyj [Young scientist]. 16 (202), pp. 329-331. Available at: https://moluch.ru/archive/202/49047/ [Accessed 4 March 2021] [in Russian].

8. Kogan, Yu.M. (2006) Krayinoznavstvo yak komponent profesijnoyi pidgotovky vchyteliv inozemnoyi movy u vyshhyx navchalnyx zakladax [Country studies as a component of professional training of foreign language teachers in higher educational institutions]. Extended abstract of candidate's thesis. Lugansk: Luganskyj nacionalnyj pedagogichnyj universytet im. T. Shevchenka. Available at: https://revolution.allbest.ru/pedagogics/00451842_0.htm [Accessed 11 March 2021] [in Ukrainian]. 
9. Krasnyh, V.V. (2002). Etnopsyholyngvystyka y lyngvokulturologyya [Ethnopsycholinguistics and linguoculturology]. Moscow [in Russian].

10. Lunhu, L. (2020). Culturological approach to the formation of the worldview of future specialists in philological specialities in the process of professional training. Naukovyj visnyk Izmayilskogo derzhavnogo gumanitarnogo universytetu. Seriya: Pedagogichni nauky [Scientific Bulletin of Izmail State University for the Humanities. Series: Pedagogical sciences], 49, pp.72-75 [in English]. DOI: 10.31909/26168812.2020-(49)-9.

11. Maslova, V.A. (2001). Lingvokulturologija: Uchebnoe posobie dlja stud. vyssh. ucheb. zavedenij [Linguoculturology: A textbook for students of higher educational institutions]. Moscow: Akademija [in Russian].

12. Taksikova, L. and Bondareva, S. Institut matematiki i informatiki MPGU. Besplatnaja platforma dlja sozdanija onlajn-dosok Padlet [Institute of Mathematics and Informatics of Moscow State University Free platform for creating online boards Padlet]. Available at: http://internet-forteacher.blogspot.com/2017/12/padlet.html/ [Accessed 7 March 2021] [in Russian].

13. Learning Apps. Available at: https://learningapps.org/display? $\mathrm{v}=$ pejv00wrn01. Kozlova, V.A. Available at: https://vseuroki.pro/ doc/interaktivnye-zadaniya-sozdannye-na-servise-leami-5807.html [Accessed 27 March 2021] [in Russian].

Вдовенко Тетяна Олександрівна, канд. філол. наук., доцент, доцент кафедри англійської філології Ізмаїльського державного гуманітарного університету (68600, Одеська обл., Ізмаїл, вул. Репіна, 12); e-mail: Vdovenko_Tanya@i.ua; orcid: https://orcid.org/0000-0001-9811-1312.

Вдовенко Татьяна Александ ровна, канд. филол. наук, доцент кафедры английской филологи и Измаильского государственного гуманитарного университета (68600, Одесская обл., Измаил, ул. Репина, 12); e-mail: Vdovenko_Tanya@i.ua; orcid: https://orcid.org/0000-0001-9811-1312.

Tetyana Vdovenko, Ph.D. in Philology, Associate Professor, Department of English Philology, Izmail State University of Humanities (68600, Odessa Region, Izmail, 12 Repina St.); e-mail: Vdovenko_Tanya@i.ua; orcid: https://orcid.org/0000-0001-9811-1312. 